\title{
Przy sublokatorskim oknie. O Oknie na tamtq stronę Władysława Szlengla
}

\author{
At the subtenant's window. About Władysław \\ Szlengel's poem The window to the other side
}

\author{
Piotr Kilanowski \\ Universidade Federal do Paraná, Kurytyba, Brazylia \\ ORCID: 0000-0003-0803-4291
}

\begin{abstract}
The aim of this article is to remind the figure of the Polish-Jewish poet of the Warsaw Ghetto, Władysław Szlengel, and to show his complex identity. Considering the problem of the poet's marginal presence in the canon of Polish culture, I attempt to reread his poem Okno na tamta strone, situating him within the context of romantic influences and other contemporary texts. The purpose of the reading is to better understand the identity of Szlengel as a representative of the Polish-Jewish intelligentsia, one of the generation of Jewish Kolumbowie, who suffered because of their marginalization and rejection in the culture they considered their own. I refer to this self-awareness, following Hanna Krall, as subtenant's identity.
\end{abstract}

Key words: Władysław Szlengel, polish-jewish identity, Warsaw ghetto’s poetry

Streszczenie: Celem niniejszego artykułu jest przypomnienie postaci polsko-żydowskiego poety getta warszawskiego, Władysława Szlengla, i ukazanie jego złożonej tożsamości. Rozważając problem marginalnej obecności poety w kanonie kultury polskiej, podejmuję próbę ponownego odczytania jego wiersza Okno na tamta stronę, sytuując go w kontekście wpływów romantycznych i innych współczesnych mu tekstów. Celem tej lektury jest pełniejsze zrozumienie tożsamości Szlengla jako reprezentanta polsko-żydowskiej inteligencji, jednego z pokolenia żydowskich Kolumbów boleśnie odczuwających swą marginalizację i odrzucenie w kulturze, którą uznawali za swoją. Ową samoświadomość, za Hanną Krall, określam mianem sublokatorskiej.

Słowa kluczowe: Władysław Szlengel, tożsamość polsko-żydowska, poezja getta warszawskiego

Od getta należało odwrócić oczy i nie patrzeć (tak jak nie patrzy się dziś często na drastyczne fotografie stamtąd), należało oddalić je od siebie, uczynić czymś obcym, bytującym gdzieś poza obszarem naszej moralnej odpowiedzialności. Szczelne zamknięcie getta (...) było elementem strategii mentalnej eksterminacji świata za murami, tego, że ulatnia się on ze świadomości ludzi po drugiej stronie.

Jacek Leociak, Doświadczenia graniczne, s. 106. 
Pomimo upływu czasu i sukcesywnego pojawiania się nowych publikacji dotyczących poety i jego dzieła, Władysław Szlengel do dziś może być określany tytułem ostatniej większej publikacji jego wierszy (Szlengel 2013) opracowanej przez Magdalenę Stańczuk: poeta nieznany. Niewątpliwie składa się na to niepełne wciąż jeszcze rozpoznanie Szlengla wiele czynników: począwszy od tych fizycznych, dotyczących mieszkańca zburzonego i spalonego miasta (i tej jego części, która najbardziej ucierpiała) i członka wymordowanej mniejszości, poprzez te, które - z elitarnego punktu widzenia - dostrzegają w nim do dzisiaj poetę mniejszego, używającego staroświeckiego, pozornie sztampowego stylu ${ }^{1}$, kończąc na tych, które powodują, że poeta piszący po polsku i cierpiący z powodu doświadczeń antysemickich i obojętności na Zagładę, które opisuje w sposób bolesny dla tej wersji historii, chcącej dostrzegać jedynie postawy polskich Sprawiedliwych, nie został do tej pory w pełni włączony do kanonu literatury polskiej. Pozostając na marginesie tego kanonu, dalej pozostaje, używając jego własnej metafory, za murkiem ${ }^{2}$, w oknie wyglądającym na stronę aryjską, z dala od centrum - wciąż zauważany przez niewielu. Oddzieleni metaforycznym murkiem pozostają również i inni wielcy autorzy polsko-żydowscy piszący w jidysz (jak np. Isaac Bashevis Singer ${ }^{3}$, Icyk Manger, Rachela Auerbach czy Abraham Suckewer) i po polsku4, nie wspominając w ogóle o piszących po hebrajsku ${ }^{5}$. Niektórzy z nich mają zapewnione swoje niekwestionowane miejsce w kanonie (np. Bolesław Leśmian, Julian Tuwim, Stanisław Jerzy Lec, Bruno Schulz, Janusz Korczak, Aleksander Wat czy Jan Brzechwa). Czasami powiązane jest to $\mathrm{z}$ wyparciem, zapomnieniem, zmarginalizowaniem lub ukrywaniem żydowskiego komponentu tożsamości (jak w przypadku Krzysztofa Kamila Baczyńskiego, Gustawa Herlinga-Grudzińskiego, Stanisława Lema czy Tadeusza Różewicza), a czasami dzięki autoidentyfikacji wyraźnie wypowiedzianej (jak w przypadku przywróconej pamięci i kanonowi w wyniku wysiłków Izoldy Kiec, Zuzanny Ginczanki czy - czyniących

${ }^{1} \mathrm{O}$ tym, że większość piszących „stojąc w obliczu tego, co nowe, a często skrajne (...) ucieka w to, co znajome, a co mieści się w (...) wzorcach kulturowych” pisał Piotr Mitzner (Mitzner 2011, 76) na podstawie spostrzeżeń Michała Borwicza. Piszący nie są w stanie stworzyć nowego języka i uciekają się do „starych, wysłużonych formuł”, klisz i sztamp. Dzieje się tak, gdyż większość autorów tworzących w sytuacjach skrajnych „była osaczona nie myślami, lecz żałosnymi strzępami myśli”, jak twierdzi Borwicz, sam znajdujący się wielokrotnie w takich okolicznościach. Nawet jeżeli wiersze Szlengla pisane w niewyobrażalnych okolicznościach (możemy dowiedzieć się o nich choćby z jego wybitnego literackiego świadectwa prozą Co czytałem umarłym) mogą być uznawane za formalnie niedoskonałe, to okoliczności ich powstania jak i zawarte w nich głębsze treści ukazane m.in. w analizach Bożeny Shallcross (Shallcross 2010) czy Tomasza Żukowskiego (Żukowski 2010) niewątpliwie kwalifikują jego twórczość wojenną do obecności w polskim kanonie literackim.

${ }^{2}$ Analize użycia słowa „murek” przez Szlengla przeprowadza Arkadiusz Morawiec (Morawiec 2015, 46-47) w artykule Szlengel w Parku Krasińskich.

${ }^{3}$ Pomimo obecności pisarstwa Singera w polskiej świadomości i festiwali noszących jego imię, oddzielenie metaforycznym murkiem przejawia się choćby w rzadkim wymienianiu go jednym tchem z noblistami piszącymi po polsku.

${ }^{4}$ Wielu z nich, w tym Szlengla, przypomina książka Ślady obecności $(2010,7)$, stawiająca sobie za cel zwrócenie uwagi na zjawiska i twórców literatury polsko-żydowskiej, którzy „stanowią margines refleksji krytycznoliterackiej".

${ }^{5}$ Przykładem może być marginalna obecność w świadomości powszechnej innego noblisty, Szmuela Jozefa Agnona, który urodził się w 1888 roku w Buczaczu, mieście Emanuela Ringelbluma i Szymona Wiesenthala. Pierwszy i jak dotąd jedyny izraelski laureat Literackiej Nagrody Nobla, porównywany czasem do Borgesa, wśród swoich głównych tematów miał świat żydowskiej Galicji i był też autorem książki legend polsko-żydowskich Polin: Sipurei agadot. 
kwestie polsko-żydowskie swoim głównym tematem - Hanny Krall, Adolfa Rudnickiego, Juliana Stryjkowskiego czy Henryka Grynberga). Szczęśliwie dokonywana od lat praca włączania tych mniej znanych autorów i tematów do ogólnej panoramy literatury polskiej przynosi widoczne, acz chyba jednak wciąż niewystarczające efekty.

W dalszym ciągu, z różnych powodów ${ }^{6}$ i pomimo całej pracy włożonej $\mathrm{w}$ uświadamianie tego faktu przez literaturę ${ }^{7}$, niewystarczająco obecny jest w ogólnej świadomości fakt, że kultura polska do czasów utworzenia w roku 1945, na mocy ustaleń jałtańskich, państwa narodowościowego była organizmem wieloetnicznym i wielokulturowym z istotnym udziałem elementu żydowskiego. Aby się o tym przekonać, wystarczy spojrzeć na historię polskiej piosenki z pierwszej połowy XX wieku. Zapominamy, że tak bardzo polski Starszy Pan A (Jerzy Wasowski) w czasie wojny musiał się ukrywać ze względu na swoje pochodzenie. Dzięki Pianiście nie mamy wątpliwości co do pochodzenia twórcy Czerwonego autobusu, Władysława Szpilmana. Wiemy również o pochodzeniu Mariana Hemara, kuzyna Stanisława Lema, ale czy podśpiewującym podczas Koncertu dla Niepodległej na Stadionie Narodowym piosenkę o miejscu pochodzenia ich obu przemknęło przez myśl, że Tylko we Lwowie (właśc. tyt. Lwów jest jeden na świecie), to przebój stworzony przez dwóch polskich Żydów ${ }^{8}$ i śpiewany przez trzeciego, postrzeganego jako arcypolskiego, batiara Tońka ${ }^{9}$ ? Albo że kolejna stała pozycja śpiewników narodowo-niepodległościowych, Czerwone maki na Monte Cassino, zostały skomponowane przez Alfreda Schütza, wyśpiewane przez Gwidona Boruckiego, po raz pierwszy nagrane przez Adama Astona i sfilmowane przez Michała Waszyńskiego - wszystkich pochodzących z rodzin żydowskich? Zresztą samo słowo „przebój” zawdzięczamy innemu słynnemu autorowi tekstów wielu piosenek Andrzejowi Włastowi, zamordowanemu podczas próby opuszczenia getta warszawskiego. Lista autorów, kompozytorów, śpiewaków i aktorów, związanych z utworami nieodmiennie kojarzonymi z „polskością”, jest długa i pełna niespodzianek. $\mathrm{Z}$ reguły nie pamięta się ich nazwisk i nie zwraca uwagi na ich pochodzenie. Świadczy to nie tylko o wybiórczej pamięci, ale również i o tym, że w tej dziedzinie nastąpiło we współczesnej pamięci całkowite zatarcie szczegółów umożliwiające pełną akceptację i wykluczające uprzedzenia, które w świadomości zbiorowej nie zezwalają, aby cokolwiek było niebinarne, jednocześnie żydowskie i arcypolskie czy polskie ${ }^{10}$. Jednym z twórców na tej długiej liście jest Władysław Szlengel, autor słów do wielu powszechnie nuconych

\footnotetext{
${ }^{6}$ Część z nich, związanych z polityką PRL, syntetycznie przedstawia Sławomir Buryła (2019, 39-41) na przykładzie literatury dotyczącej getta warszawskiego.

${ }^{7}$ Wśród wielu takich dzieł wymieńmy tu tylko fundamentalne dla przywracania tej pamięci w ostatnich latach Księgi Jakubowe Olgi Tokarczuk i Króla Szczepana Twardocha wraz z jego świetną adaptacją serialową.

${ }^{8}$ Kompozytorem był genialny autor wielu przedwojennych szlagierów, Henryk Wars, a autorem słów, zamordowany, najprawdopodobniej w Obozie Janowskim, Emanuel Szlechter, również twórca dziesiątek tekstów popularnych przebojów.

${ }^{9}$ Tońko lub Tońcio to postać stworzona i interpretowana przez aktora i doktora prawa, Henryka Vogelfängera.

${ }^{10}$ Bardzo dziękuję Katarzynie Kuczyńskiej-Koschany za zwrócenie mi uwagi na tę kwestię.
} 
piosenek. Najbardziej znane z nich to: Panna Andzia ma wychodne, Chodź na piwko naprzeciwko, dwa szlagiery wyśpiewane przez Wierę Gran, Tango notturno i Jej pierwszy bal (skomponowany przez Szpilmana, cała trójka spotkała się ponownie w „Café Sztuka” w getcie warszawskim) czy Jadziem Panie Zielonka, którego refren stał się powiedzeniem obecnym do dziś w zbiorowej świadomości językowej, pomimo tego, że nie udało się do niej trafić autorowi.

Szlengel niewątpliwie jest coraz częściej przypominany. Wśród prób zapełnienia owej luki w pamięci zbiorowej możemy wymienić wydanie płyty z jego piosenkami w roku $2015^{11}$ czy realizację w 2018 roku spektaklu Teatru Telewizji w reżyserii Artura Hofmana ${ }^{12}$, w całości opartego na piosenkach i wierszach Szlengla, do których muzykę skomponował Hadrian Filip Tabęcki. W tym samym roku izraelski zespół El Hameshorer podczas otwarcia festiwalu Warszawa Singera dał koncert piosenek, stworzonych do hebrajskich tłumaczeń wierszy Szlengla (pióra Haliny Birenbaum), pod kamienicą na ulicy Waliców 14, w której ongiś mieszkał poeta. Na osobną uwage zasługuje niezwykły album Biała Warszawa. Ballada o polskich poetach żydowskich autorstwa Krieger Telus Band z 2014 roku. Właśnie przez muzykę artyści próbują włączyć do powszechnej świadomości twórczość poetów, którzy „byli Polakami, choć z plemienia Izraela”13. Piosenka na podstawie wiersza Szlengla Rzeczy sąsiaduje tu z utworami skomponowanymi do tekstów takich poetów, jak Icyk Manger, Mordechaj Gebirtig czy Aharon Zeitlin. Co ciekawe, wszystkie te przedsięwzięcia łączą się z podkreśleniem muzyczności wierszy Szlengla, który, jako się rzekło, był wziętym tekściarzem.

Dzięki zbiorom utworów poety, najpierw szerzej upowszechnionym w antologii Pieśń ujdzie cało... opracowanej przez Michała Borwicza (1947), a później w tomikach opracowanych przez Irenę Maciejewską (1979, pierwsze wydanie w 1977) i Magdalenę Stańczuk (2013), mamy dostęp do większości tego, co cudem zachowało się z jego obfitej spuścizny literackiej, w przypadku ostatniej z książek - wzbogaconego o twórczość przedwojenną. O swoich wojennych wierszach Szlengel, poeta tworzący wyłącznie po polsku, pisał w przedmowie, symptomatycznie zatytułowanej Do polskiego czytelnika, że pojawiały się „jak uśmiechy uspokajające umierającego między jednym drgnieniem bólu a drugim" (Szlengel 2013, 198). Zaiste tytuł tej przedmowy jest świadectwem, że „język nasz

${ }^{11}$ Płyta „Tanga Szlengla” opracowana przez Katarzynę Zimek była dodatkiem do Gazety Wyborczej 19-20.05 2015. Wiele z tekstów na płycie zostało napisanych wspólnie z Józefem Lipskim, z którym Szlengel współpracował również w "Café Sztuka”, a muzykę do najbardziej znanych tang andrusowskich Panna Andzia ma wychodne, Chodź na piwko naprzeciwko i Jadziem Panie Zielonka skomponował kolega Szlengla z podwórka na Walicowie, Bolesław Mucman. Obaj, podobnie jak Szlengel, zostali zamordowani w czasie wojny.

${ }^{12}$ Spektakl Okno na tamta strone został wyemitowany w TVP1 w 75 rocznice wybuchu powstania w getcie warszawskim, 19.04.2018.

${ }^{13}$ Cytat pochodzi z tekstu piosenki Jacka Telusa Pierwsza ballada o polskich poetach żydowskich otwierającej wzmiankowaną płytę. 
stał się im obcy [w innej wersji:] ${ }^{14}$ język ich stał się nam obcy) / jak język innej planety”, jak napisał, patrząc z „aryjskiej” strony na getto w płomieniach, Czesław Miłosz (Miłosz 2011, 193-194). Niewątpliwie utwory „poety getta”, ocalałe z czasów wojny, należą do kategorii tych, których: „istnienie (...) jest wyzwaniem dla nas wszystkich" (Leociak 2016, 7). W innym miejscu o Zagładzie jako wyzwaniu dla refleksji o literaturze pisał Przemysław Czapliński (Czapliński 2004).

Wyzwanie rzucone przez istnienie tekstów Szlengla podejmowane jest przez literatów ${ }^{15}$ i badaczy. Jednym z pierwszych, którzy omawiali dzieło poety, był Emanuel Ringelblum (Ringelblum 1983, 580-585). W kontekście jego notatek i całego Archiwum Ringelbluma pisze o Szlenglu w swej książce Samuel D. Kassow (Kassow 2010, 288-297). Zklasycznych rozważań i prezentacji należy zacytować wstępy do antologii: Borwicza (1947), Maciejewskiej (Szlengel 1979) i Stańczuk (Szlengel 2013), jak również ważną w swoim czasie i istotną w zamyśle książkę Natana Grossa (Gross 1993), gdzie Szlengel i jego wiersze pojawiają się dość często. O Szlenglu jako o poecie łączącym w sobie polskość i żydowskość, który zmuszony jest do życia w świecie rozdzielonym murem przez boga podziału Binariusa, pisze Władysław Panas (Panas 1996). Rozważania o owym tragicznym rozdarciu poety, widzianym w kontekście śmierci i pamięci o niej na podstawie lektury wiersza Dwie śmierci, kontynuuje Marian Kisiel (Kisiel 2015, 21-31). Problem złożonej tożsamości etnicznej Szlengla pojawia się również w kontekście tematu bezdomności - u Madeleine G. Lévine (Levine 1999) i w kontekście naznaczenia żydowskością w artykule Beaty Przymuszały (Przymuszała 2011). Tomasz Żukowski (Żukowski 2005), ukazując zakorzenienie poety w polskiej tradycji romantycznej, zestawia Dzwonki Szlengla z Lilijami Mickiewicza ${ }^{16}$ i, w innej ze swoich prac (Żukowski 2010), dogłębnie analizuje wiele z wierszy Szlengla, zwracając uwagę na ciągłe, celowe współistnienie sprzeczności w tym dziele poetyckim, jego niejednoznaczność i wszechobecną, gryzącą ironię jako strategię świadectwa, ukazującego bunt marginesu przeciw centrum. Temat spokrewniony z ironią, bo krążący wokół czarnego humoru Szlengla, podejmuje Adam Kowalczyk (Kowalczyk 2015). Z kolei Dandys i żydowskie rupiecie, rozdział książki Bożeny Shallcross (Shallcross 2010,

\footnotetext{
${ }^{14}$ Kwestia dwóch wersji Campo di Fiori Miłosza została omówiona przez Natana Grossa w rozdziale Dzieje jednego wiersza w przełomowej pozycji Poeci i Szoa $(1993,84-89)$ i poszerzona w artykule Marcina Wołka (2011). Natan Gross bodaj pierwszy zestawił bezpośrednio ostatnią linijkę wiersza Miłosza („bunt wznieci słowo poety”) z wierszem Szlengla Kontratak, jako słowem wzniecającym bunt. Wspominają o tej właśnie roli wiersza zagrzewającego do rebelii m.in. Marek Edelman (Krall 2017, p. 60), Michał Borwicz (1947, 37) czy Szymon Rogoziński, cytowany przez Arkadiusza Morawca $(2015,41)$.

${ }^{15}$ Najważniejszych z nich wylicza i omawia Morawiec (2015, 51-52): Adolf Rudnicki, Henryk Grynberg, Piotr Mitzner, Irit Amiel, Krzysztof Boczkowski.

${ }^{16}$ Ballada Mickiewicza pojawia się również w kontekście Zagłady w książce Hanny Krall Wyjątkowo długa linia, prowokując refleksje, dlaczego właśnie ten wiersz, pełen grozy związanej z obecnością zjawisk nadprzyrodzonych i zbrodni współistniejącej z normalnym światem, występuje w kontekście grozy i zbrodni Zagłady i normalnego świata istniejącego obok; zob. Krall 2017, 852-854 i 862. Żukowski (2005, 242), pisząc o Dzwonkach, sugeruje: „Paralela z Lilijami pozwala wydobyć całą komplikację spojrzenia na polską tożsamość z perspektywy polskiego Żyda, całkowicie zasymilowanego, a jednocześnie skazanego na getto. (...) Braterska solidarność nie zostaje zerwana wprost, ale przez zaniechanie."
} 
51-74), poświęcony Szlenglowi, po mistrzowsku podkreśla i łączy elementy dokumentalne i artystyczne $\mathrm{w}$ jego wierszach, dzięki skupieniu uwagi na roli przedmiotów w tej twórczości i na arcydzielnym użyciu metonimii przez poetę. Rzeczy, jako wyraziciele doświadczenia ludzkiego w poezji Szlengla, są również obiektem rozważań Karoliny Koprowskiej (Koprowska 2016). W kontekście literatury Zagłady analitycznego przeglądu różnych wierszy Szlengla ${ }^{17}$ dokonuje Piotr Matywiecki (Matywiecki 2012). Kończąc wreszcie ten krótki i niepełny przegląd odbioru Szlengla, dodam, iż cytowany już Arkadiusz Morawiec analizuje wiersz Piotra Mitznera i mierzy się z mitami narosłymi wokół poety. Na przykładzie rozważań o dacie śmierci poety getta, umieszczonych w kontekście ostatnich świadectw o nim (m.in. Skwara 2003, Najberg 1993, Rogoziński 1994), Morawiec unaocznia niepewność i skazanie na domysły historyków, biografów i literaturoznawców mierzących się z legendą Szlengla. Przykładami takiego skazania mogą być historia odnalezienia przez Halinę Birenbaum (Birenbaum 1998, 139) wiersza Obrachunek $z$ Bogiem, historia odtwarzania wiersza List, przytoczona przez Natana Grossa (Gross 1993, 40), historia odnalezienia wierszy poety w pożydowskim stole i w Archiwum Ringelbluma, publikacja dotąd nieznanych, domniemanych i fragmentarycznych wierszy poety $\mathrm{w}$ tomie Archiwum Ringelbluma, poświęconym utworom literackim z getta warszawskiego (Żółkiewska, Tuszewicki 2017, 99-119), czy ostatnia lokalizacja kilku wierszy przedwojennych, które nie znalazły się w tomie opracowanym w 2013 przez Magdalenę Stańczuk ${ }^{18}$. Innym przykładem może być fakt, że dopiero w 2015 roku, na podstawie badań w archiwach, grupa naukowców (Flatau, Zimek, Lerski 2015) ustaliła, że Szlengel urodził się w 1912 (a nie jak dotąd uważała większość o nim piszących w 1914), ustalając również dane i personalia niektórych z jego bliskich. Jak widać, pomimo upływu prawie osiemdziesięciu lat od śmierci poety, temat jego życia i twórczości daleki jest od wyczerpującego i definitywnego zbadania, a okoliczności zawsze będą skazywać nas na przypuszczenia i fragmentaryczność. Badacz Szlengla, tamtej epoki, autorów i tekstów może powtórzyć za innym nieocalałym, Brunonem Schulzem (Schulz 2019, 506): „Tak tedy będziemy zbierali te aluzje, te ziemskie przybliżenia, te stacje i etapy po drogach naszego życia, jak ułamki potłuczonego zwierciadła. Będziemy zbierali po kawałku to, co jest jedno i niepodzielne".

Jako tłumaczowi dane mi było- również - zmierzyć się z wyzwaniem, o którym piszą Czapliński i Leociak. Efektem była edycja krytyczna poezji oraz prozy gettowej Szlengla, opatrzona przypisami i wydana w Brazylii (Szlengel 2018). Oprócz utworów poety książka zawiera również tekst

${ }^{17}$ W tomie Literatura polska wobec Zagłady (1939-1968), w części dotyczącej prozy piszą o Szlenglu również Sławomir Buryła i Dorota Krawczyńska.

${ }^{18}$ Adresy bibliograficzne kilkunastu utworów Szlengla opublikowanych w prasie przedwojennej podał Adam Kowalczyk w rozprawie doktorskiej Władysław Szlengel. Autor - Dzieło - Publiczność, napisanej pod kierunkiem Krystyny Latawiec w 2020 roku na Uniwersytecie Pedagogicznym w Krakowie. Niestety, dotąd nie udało mi się uzyskać dostępu do tej pozycji, niewątpliwie arcyważnej dla recepcji Szlengla, zatem sygnalizuję jedynie jej istnienie. 
Ringelbluma o Szlenglu i rozdziały komentujące twórczość artysty, autorstwa Carlosa Reissa, dyrektora Muzeum Holokaustu w Kurytybie, Marcela Paivy de Souzy, mojego kolegi z polonistyki na Uniwersytecie Federalnym Parany, oraz wstęp i rozdział - napisane przeze mnie. Kwestia tłumaczenia utworów Szlengla na portugalski to temat na osobny artykuł. Tutaj pragnąłbym podzielić się jedynie refleksjami interpretacyjnymi, jakie nasunęły mi się przy tłumaczeniu jednego z najbardziej znanych wierszy Szlengla, Okno na tamtq stronę, który dał tytuł antologii A janela para o outro lado.

Już sama kwestia tytułu wywołała u mnie refleksję związaną z doświadczeniami tłumacza. Otóż w jednym z wierszy Paula Leminskiego ${ }^{19}$, który przełożyłem na polski, Ouverture la vie en close, pojawiają się rozważania etymologiczne na temat słowa janela, czyli okno. Autor wskazuje na nietypowe w porównaniu do innych języków pochodzenie tego słowa w portugalskim, wywodzącego się od łacińskiego janua/januella oznaczającego drzwi/drzwiczki (Leminski 2013, 65). Łacińskie słówko pochodzi od imienia staroitalskiego boga, opiekuna drzwi i bram, Janusa. A Janus, jak wiemy, ma dwie twarze, patrzy w dwie strony jednocześnie, zupełnie jak okno, które pozwala wyjrzeć na zewnątrz i spojrzeć do wnętrza. Janus może symbolizować archetyp poety-kapłana, pośrednika pomiędzy światem duchowym i materialnym. Może być również doskonałą analogią dla zrozumienia Szlengla, człowieka patrzącego jednocześnie w dwie strony, identyfikującego się z tożsamościami polską i żydowską, człowieka, który jest wyrazicielem myśli, uczuć i doświadczeń ludzi zamkniętych w getcie i łącznikiem pomiędzy światem mówiącym w jidysz i po polsku, pomiędzy światem w murach i za murami. Pisał wszak poeta we wstępie Do polskiego czytelnika:

Wiersze, w które wejdziecie, moi drodzy, bez opasek, to dżungla, w której niełatwo znajdziecie drogę. Tematyka i rekwizyty są dla was obce i niezrozumiałe, wymagają wielu komentarzy. Są słowa i pointy, których głębie i przeraźliwy smutek poznać można po przygotowaniu, jakie dać może tylko życie za murem i pod pejczem esesmanów (Szlengel 2013, 198).

Okno Szlengla jest więc oknem janusowym, usytuowanym na progu światów, pozwalającym autorowi wyjrzeć poza mury getta i pozwalającym nam z tej strony muru, z tej strony historii, z tej strony dzielącego nas metaforycznego murka, zajrzeć do getta. Spojrzenie Szlengla jest cenne, bo jest tą wizją, o której pisał Jacek Kuroń (Czapliński 2015, 41) w kontekście filmu Shoah:

Jaka jest różnica między Polakami a Żydami w czasie okupacji? Ano taka, że ja jechałem przez getto tramwajem na basen i oglądałem po tamtej stronie muru umierających ludzi. Lanzmann umieścił kamerę w oczach tego Żyda, który wtedy patrzył na mnie. On musiał mnie widzieć tak, jak widzi Lanzmann tych Polaków, i trudno mu się dziwić ${ }^{20}$.

${ }^{19}$ Ciekawą zbieżnością z podwójną tożsamością Szlengla jest fakt, że Leminski określał się jako Polak i Brazylijczyk, choć nie władał już prawie językiem polskich przodków, a pisał po portugalsku. ${ }^{20}$ Podobny dysonans podkreśla Jacek Leociak $(2018,118-119)$, analizując spojrzenia na getto z okien jadącego przez nie tramwaju. Autor zestawia kontrastujące ze sobą spojrzenia Zygmunta 
Z drugiej strony Szlengel jest Żydem-allosemitą, jak pisze (za Magdaleną Stańczuk) Beata Przymuszała (Przymuszała 2011, 156). Jest też jednym z niewielu poetów getta piszących po polsku (Żółkiewska, Tuszewicki 2017, $\mathrm{XXV}$ ), a to powoduje, że jego słowa otwierają przed nami jeszcze bardziej sproblematyzowaną perspektywę. Szlengel bowiem jest Żydem i Polakiem jednocześnie, ale jego tożsamość żydowska jest tożsamością zdystansowaną (Przymuszała 2011, 156-159), a tożsamość polska to tożsamość bolesnego odrzucenia. Nawet jeżeli w swoich wierszach (najbardziej chyba emblematycznie w wierszu Dwie śmierci) opisuje to, co Hanna Krall w Zdażyć przed Panem Bogiem, a potem w Sublokatorce, zdefiniowała jako jasność i ciemność (Panas 1996, 112), czyni to z perspektywy tragicznego sublokatora w obydwu kulturach. Metafora sublokatora, stworzona przez Krall, doskonale określa poczucie pozornej akceptacji, wyobcowania i niepełnowartościowości, które może być porównywalne z odrzuceniem obcego, imigranta jako kogoś gorszego, kto nigdy nie stanie się pełnoprawnym uczestnikiem wspólnoty ${ }^{21}$, wiecznie pozostając na jej marginesie. Dogłębne badania nad tematem takiego wykluczania nowych członków przez wspólnoty zasiedziałe, marginesu przez centrum (por. obecność tych elementów u Szlengla w: Żukowski 2010) przeprowadzili Norbert Elias (niemiecki Żyd z Wrocławia) i John L. Scotson (1965).

Sublokatorstwo jako kategorię kultury polskiej zaproponowały Elżbieta Janicka i Joanna Tokarska-Bakir, widząc w sytuacji bohaterki Krall zjawisko paradygmatyczne:

Kłopoty sublokatorek/sublokatorów zazwyczaj zaczynają się, zanim jeszcze sformułują one/oni jakiekolwiek roszczenie. Wystarczy, że zaczną problematyzować swoją sytuację. Czynią bowiem wówczas widocznym to, co ma pozostawać niewidoczne i niewyartykułowane. Przekonała się o tym Sublokatorka z prozy Hanny Krall. Hanna Krall natomiast - nazywając zjawisko - dostarczyła nowej kategorii opisu, a więc także narzędzia analizy i krytyki kultury opartej na dominacji i podporządkowaniu. Związane z nimi praktyki tak skutecznie pacyfikują zbiorową świadomość, że inne sposoby myślenia i postępowania wydają się w najlepszym razie marginalne i niezgodne z intuicją, w najgorszym zaś - szalone. Dominacja symboliczna zakłada pewien rodzaj wspólnictwa ze strony tych, którzy jej podlegają. Nie chodzi tu ani o bierne podporządkowanie, ani swobodny wybór. Posługując się tą paradoksalną ofertą „przymusowego wyboru”, grupa dominująca narzuca instytucjom i aktorom społecznym dopuszczalną listę tematów - bez uciekania się do otwartej przemocy (Janicka, Tokarska-Bakir 2013, 1).

\footnotetext{
Zaremby, współczującego obserwatora z wnętrza tramwaju, i Poli Rotszyld, rozczarowanej mieszkanki getta widzącej w obserwatorach jedynie bezdusznych gapiów.

${ }^{21}$ Prócz Sublokatorki, gdzie autorka ukazuje temat "sublokatorstwa” na podstawie bohaterki posiadającej sporo podobieństw do niej samej, w innej książce, zatytułowanej Wyjątkowo długa linia, jedną z bohaterek opowieści czyni Krall trochę zapomnianą polsko-żydowską poetkę, Franciszkę Arnsztajnową. Tak pisarka $(2017,820)$ mówi na jej przykładzie o dramacie wykluczenia: „Franciszka Arnsztajnowa zwróciła się do żydowskiego Boga ( $<<$ Boże mych ojców, wielki Boże Izraela...>>) jeden raz, kiedy zaczynała pisać wiersze. Skarżyła Mu się. Opowiadała Mu o świecie - że ją odtrąca. Że nie życzy sobie jej obecności. Że ma dla niej, obcej, słowa bezlitosne: <<...I nigdy nam braćmi twe dzieci nie będą, I nigdy ci matką rodzoną zwać ziemię, A imię twe -tułacz... precz od nas, przybłędo>>."
} 
Autorki opisały również sytuację sublokatora idealnego. Wielu spośród twórców wymienionych powyżej (np. Michał Waszyński, Gustaw Herling-Grudziński, Stanisław Lem czy Tadeusz Różewicz) wpisuje się w tę kategorię i spojrzenie na nich z tej perspektywy wzbogaca lekturę ich twórczości.

Sublokator idealny to taki, który zaprzecza własnemu statusowi sublokatora. Jego rolą jest poświadczać wyidealizowany autowizerunek lokatora. Sublokator dostarcza lokatorowi alibi w razie oskarżenia tego ostatniego o praktyki dyskryminacyjne. Szczególnie cenny jako panaceum na innych sublokatorów - takich, którzy nie upraszają o tolerancję, lecz żądają równouprawnienia (Janicka, Tokarska-Bakir 2013, 2).

Aplikacja kategorii „sublokatorstwa” i stworzonej przez Irit Amiel kategorii „osmalenia” (sytuacji tych, którzy cudem przeżyli Zagładę, ale noszą ją w sobie do końca życia) została dokonana, przy okazji analizy prozy tej autorki, przez Agatę Patalas (2018). W swoim tekście badaczka nie tylko twórczo aplikuje obie kategorie, ukazując związki między nimi $($ " $<<$ sublokatorstwo egzystencjalne>> jest podstawową cechą <<osmalenia>>", Patalas 2018, 210), ale jasno wskazuje na potrzebę włączenia pojęcia sublokatorstwa do dydaktyki polonistycznej jako pozwalającej lepiej zrozumieć nie tylko Zagładę, ale i świat wokół nas ${ }^{22}$.

Jedną z prób artystycznego odczytania problemu przedstawił nam w Lokatorze inny uciekinier z getta, Roman Polański (przy porównaniu warto zwrócić uwagę na obecność i znaczenie okna w tej wizji oraz na fakt, że autorem literackiego pierwowzoru był Roland Topor, Francuz pochodzenia polsko-żydowskiego). A to, że każdy poeta to outsider, wykluczony, Żyd, żyjący na marginesie oficjalnego nurtu kultury, stwierdziła Marina Cwietajewa, a przybliżyła Katarzyna Kuczyńska-Koschany (2013) w arcydzielnej próbie poszerzenia kanonu o antytotalitarne gesty poetyckie.

Wracając do okna w getcie, jak pisze Leociak:

budzi [ono] tęsknotę, daje namiastkę wolności. Ale wszystko to sprawia jeszcze większy ból, albowiem otwarte okno staje się paradoksalną figurą uwięzienia (...). Z getta uciec można tylko do getta. Okno w dzielnicy zamkniętej ma co najmniej podwójną symbolikę. Jest $\mathrm{z}$ jednej strony wyrazem pragnienia pokonania przepaści, nadziei na spotkanie ze światem, z ludźmi. Jest znakiem tęsknoty za otwartą przestrzenią, za wolnością. Z drugiej zaś strony boleśnie uzmysławia tę przepaść, odcięcie i odrzucenie (Leociak 2016, 196-197).

Jest zatem - tak jak i sam poeta - naznaczone podwójnością, jest znakiem jednocześnie wolności i zniewolenia, bezpieczeństwa i odrzucenia.

Czas spojrzeć na wiersz Szlengla (Szlengel 2013, 200-201):

Mam okno na tamtą stronę, bezczelne żydowskie okno na piękny park Krasińskiego, gdzie liście jesienne mokną... Pod wieczór szaroliliowy

${ }^{22}$ Za zwrócenie uwagi na oba powyżej omawiane teksty serdecznie dziękuję Katarzynie Kuczyńskiej-Koschany. 
składają gałęzie pokłon

i patrzą się drzewa aryjskie

w to moje żydowskie okno...

A mnie w oknie stanąć nie wolno

(bardzo to słuszny przepis),

żydowskie robaki... krety...

powinni i muszą być ślepi.

Niech siedzą w barłogach, norach

$\mathrm{w}$ robotę $\mathrm{z}$ utkwionym okiem

i wara im od patrzenia

i od żydowskich okien...

A ja... kiedy noc zapada...

by wszystko wyrównać i zatrzeć,

dopadam do okna w ciemności

i patrzę... żarłocznie patrzę...

i kradnę zgaszoną Warszawę,

szumy i gwizdy dalekie,

zarysy domów i ulic,

kikuty wieżyc kalekie...

Kradnę sylwetkę Ratusza,

u stóp mam plac Teatralny,

pozwala księżyc Wachmeister

na szmugiel sentymentalny...

Wbijają się oczy żarłocznie,

jak ostrza w pierś nocy utkwione,

w warszawski wieczór milczący,

w miasto me zaciemnione...

A kiedy mam dosyć zapasu

na jutro, a może i więcej...

żegnam milczące miasto,

magicznie podnoszę ręce...

zamykam oczy i szepcę:

- Warszawo... odezwij się... czekam...

Wnet fortepiany w mieście podnoszą milczące wieka... podnoszą się same na rozkaz ciężkie, smutne, zmęczone... i płynie ze stu fortepianów w noc... Szopenowski polonez...

Wzywają mnie klawikordy, w męką nabrzmiałej ciszy płyną nad miastem akordy spod trupio białych klawiszy...

Koniec... opuszczam ręce... wraca do pudeł polonez...

Wracam i myślę, że źle jest mieć okno na tamtą stronę... 
Wiersz jest pozornie prosty, zawiera jednak w sobie wiele podwójnych znaczeń i zbudowany jest na opozycjach. Tomasz Żukowski zwraca uwagę:

Swoistość komunikatu z getta zasadza się na ironii, która pozwala współistnieć sprzecznościom i utrzymywać je w ciągłym napięciu. Szlengel bierze stronę banału. Mówi z marginesu ujawniając charakterystyczną dla niego mieszankę koszmaru, trywialności, wstydu i współczucia, które nie mogą znaleźć dla siebie stosownej formy wśród uznanych w kulturze sposobów mówienia (Żukowski 2010, 143).

Pozorną prostotę wierszy Szlengla tak opisuje Sławomir Buryła:

Szlengel - podobnie jak Jurandot - sięga po tradycyjną formę, by mówić o doświadczeniach granicznych. Ta prostota jest przejmująca. To z pewnością najwybitniejszy poeta getta, co więcej, jeden z najwybitniejszych poetów Zagłady. Jego Kartka $z$ dziennika "akcji”, Już czas, Rzeczy, Okno na tamta stronę czy Mała stacja Treblinki to genialna, choć przerażająca, kronika dziejów miasta za murem. Ale ta prostota jest zdradliwa. Siła liryki Szlengla tkwi w „podwójnym kodowaniu” (Buryła 2019, 37).

Jak przejawia się w tym wierszu owo „podwójne kodowanie”? Pozornie wiersz wydaje się świadectwem poetyckim Szlengla o tym, co widać przez jego okno w szopie szczotkarzy na Świętojerskiej 34. Widać Ogród Krasińskich i wieże Warszawy. Okno jest „bezczelne”, pozwala sobie na niedozwolone spojrzenie poza mur na nieobecną w getcie zieleń parku. Podczas zmierzchu widać jedynie „drzewa aryjskie” (w getcie drzew prawie nie było) i tylko one kłaniają się z szacunkiem wobec bólu poety, w odróżnieniu od ludzi z „aryjskiej” strony. Ci albo go nie zauważają, albo pozbawiają prawa do człowieczeństwa i zabraniają mu podchodzić do okna, grożąc śmiercią. On sam musi ukrywać się w podziemiach, jak kret czy robak. Metafora Żyda-kreta, użyta przez Szlengla, prawdopodobnie zainspirowała strażnika-kreta Miłosza z wiersza Biedny chrześcijanin patrzy na getto (zdaje się sugerować to Morawiec 2015, 48-49) i kreta z wiersza Jerzego Ficowskiego Ściana płaczu („więc jeszcze kret/ nosi żałobę/ i budzi kretowiska/ wyrzuty ziemi", Ficowski 2014, 140). Obraz Szlengla patrzącego przez okno jest jednak bardziej skomplikowany. Czuje się on odrzucony i osamotniony. Czuje, że los niewolnika przeznaczonego na śmierć, „podczłowieka”, nie spotyka się ze zrozumieniem czy nawet zauważeniem przez kogokolwiek po drugiej stronie muru - z wyjątkiem „aryjskich drzew”.

Żeby obraz pogłębić, należy spojrzeć na Szlengla jako na człowieka o podwójnej tożsamości - pisarza, który podziwiał skamandrytów i Tuwima (ten był jego znajomym i mistrzem i, podobnie jak on, satyrykiem i tekściarzem) - i młodzieńca, który - tak jak Kolumbowie (choć nieco od nich starszy) - wychowany był w polskiej tradycji romantycznej ${ }^{23}$. Odpowiadając na głosy stanowczego sprzeciwu, które do mnie dotarły w związku z użyciem sformułowania „żydowski Kolumb”, jako niewiele precyzującego i powiązanego z Romanem Bratnym, człowiekiem o skomplikowanej biografii, chciał-

${ }^{23} \mathrm{Na}$ temat obecności i wpływów romantyzmu na poezję doby wojennej, zwłaszcza na pokolenie Kolumbów, pisał Piotr Mitzner (2011), szczególną uwagę poświęcając temu zagadnieniu w eseju Romantyczna pułapka. 
bym podkreślić, że samo sformułowanie, wprowadzone przez Sławomira Buryłę ${ }^{24}$, miało za jeden ze swoich celów włączenie żydowskich rówieśników Kolumbów do polskiego mitu, od którego pozostawali (nadal pozostają?) oddzieleni owym metaforycznym murkiem, o którym była już mowa. Co do samego określenia pokolenia, które przyszło na świat w latach 20. XX w. jako Kolumbów, to wydaje mi się, że określenie i mit przez nie stworzony już dawno odkleiły się nie tylko od Romana Bratnego, ale i od jego powieści, i funkcjonują niezależnie od niego w historiografii nie tylko literackiej. Niezależnie od złożonej biografii Bratnego, powstańca warszawskiego i więźnia oflagów, a potem autora literatury, w której istniały i elementy antysemickie i takie, które propagandowo fałszowały rzeczywistość, uważam, że Kolumbowie. Rocznik 20 nadal pozostają ważną pozycją w historii literatury polskiej, dziełem godnym pamięci i badań pomimo problematycznej biografii autora, a może nawet wręcz w jej kontekście (bo ta ukazuje zawiłości historii).

Warto tu przypomnieć, że Stanisław Skiernik, Kolumb z powieści Bratnego, podobnie jak jeden z jego pierwowzorów ${ }^{25}$, Stanisław Likiernik (1923-2018), byli pochodzenia żydowskiego, tak samo jak sztandarowy twórca pokolenia Kolumbów, Krzysztof Kamil Baczyński. Obaj zresztą doskonale ilustrują kwestię sublokatorstwa jako kategorii kultury polskiej. Likiernik (podobnie jak powieściowy Skiernik) jest nazywany przez zwierzchnika Machabeuszem, pomimo niezgody na ten pseudonim ${ }^{26}$, jako nieprzystający do jego poczucia tożsamości i wyjawiający niebezpieczną prawdę o jego pochodzeniu. Baczyński z kolei pisze - gdy trwało powstanie w getcie - wiersze, które do dziś bywają jednoznacznie interpretowane jako wiersze o Polakach ${ }^{27}$. W samej powieści Bratnego znajdujemy nie tylko obrazy otwartego (jak choćby szmalcownicy) i utajnionego (wzmiankowana powyżej kwestia pseudonimu Machabeusz) antysemityzmu istniejącego w społeczeństwie polskim (obok postaw wręcz przeciwnych), ale i niesławną karuzelę na Placu Krasińskich, egzekucje Żydów dokonywane podczas powstania warszawskiego przez ugrupowania prawicowe (Alina, siostra Kolumba i żona Jerzego, wraz z dzieckiem padają ofiarą byłego policjanta szmalcownika, który przystał do powstania), lecz i takie tematy tabu

${ }^{24}$ O Szlenglu i innych żydowskich Kolumbach pisze Sławomir Buryła (2013, 13-113) w części książki zatytułowanej Żydowscy Kolumbowie - (Nie)znana historia, wskazuje tam również na powody nieobecności i niepopularności tego wątku w historiografii literackiej (s. 109-112).

${ }^{25}$ Drugim z pierwowzorów bohatera powieści był Krzysztof Sobieszczański (1916-1950), on także nieco starszy od pokolenia Kolumbów i będący również osobą o niejednoznacznej biografii, łączącej przedwojenne niemieckie więzienie, Pawiak, Auschwitz, bohaterską walkę w Kedywie i w powstaniu warszawskim z powojennymi przedsięwzięciami w Europie Zachodniej jakby rodem z powieści łotrzykowskiej czy filmów gangsterskich. Więcej na jego temat można dowiedzieć się z nominowanej do Nagrody Nike książki Emila Marata (2018) Sen Kolumba.

${ }^{26}$ Zob. Wójcik M., Marat E., Likiernik S., 2014, 122-125.

${ }^{27}$ Jako przykład moge przytoczyć interpretację wiersza napisanego w kwietniu 1943, prawdopodobnie w czasie gdy trwało już powstanie w getcie, *** (Byłeś jak wielkie stare drzewo), odczytywanego jako odnoszącego się do narodu polskiego i pojawiającą się jako jedną z pierwszych przy wyszukiwaniu go przez Google: https://www.bryk.pl/wypracowania/jezyk-polski/wiersze/20893-nasz-narod-jest-jak-drzewo-analiza-wiersza-k-k-baczynskiego.html (dostęp: 01.05.2021). Temat podwójnej tożsamości poety i niejednoznacznego sposobu jej zapisywania w wierszach, nawiązującego tak do romantycznego mitu, jak i poczucia wydziedziczenia, omawia Tomasz Żukowski (2004). 
w rzeczywistości PRL-u, jak Katyń czy tortury i prześladowania AK-owców pod okupacją sowiecką i w początkach Polski Ludowej. Powieść Bratnego, przekazuje wiele demitologizującej prawdy o powstaniu warszawskim i konspiracji, prawdy niewygodnej - tak wtedy jak i dziś - bo przedstawiającej je w całej złożoności jako heroiczny i zarazem tragiczny absurd prowadzący do rzezi miasta spowodowanej politycznymi decyzjami dowództwa. Jest opowieścią ukazującą tragiczne uwikłanie polskiej młodzieży inteligenckiej w historię i jej tytuł wspaniale definiuje dramat pokolenia, który stał się również udziałem Szlengla i innych żydowskich Kolumbów: konflikt pomiędzy przerażającą rzeczywistością wojny, odkrywanej jako nowy świat, a zupełnie odmiennymi wyuczonymi wartościami, bazującymi na mitach romantycznych i patriotycznych. Nieczęsto jednak w historii literatury mówi się o Szlenglu jako o jednym z pokolenia Kolumbów. A wiele z inspiracji gettowych wierszy Szlengla wywodzi się właśnie z literatury romantycznej.

Zauważamy to we wspomnianej próbie dialogu pomiędzy dwiema balladami grozy: Dzwonkami i Lilijami (Żukowski 2005, 241-243). W wierszu Szlengla możemy dostrzec też obraz zjaw-dziadów, duchów dawnych lokatorów przyzywanych dzwonkami w przestrzeni pożydowskiego mieszkania. Możemy dostrzec obraz wadzenia się z Bogiem, przypominający Konrada (zapewne odziedziczonego przez niego z żydowskiej tradycji zmagań ze Stwórcą), w wierszu Obrachunek $z$ Bogiem (Bóg nie jest co prawda carem, za to chodzi bez opaski i ma paszport urugwajski) czy też, porównywalne z Konradowym, bluźniercze oskarżenie wobec niego w wierszu Już czas, gdzie Bóg, ponosząc winę za całą swoją obojętność, zmuszony jest do podzielenia losu żydowskiego i umiera w komorze gazowej. W wierszu $Z a$ pięć dwunasta pierwszy wers „nam schodzić nie kazano” (Szlengel 2013, 293) od razu sytuuje nas w romantycznej tradycji Reduty Ordona, a w wierszu Święta Tomasz Żukowski $(2010,150)$ dostrzega nawiązanie brzmieniowo-konstrukcyjne do ballady Trzech budrysów, połączone przez kontrast $\mathrm{z}$ „pogodną gawędą” Mickiewicza.

Zresztą polska poezja romantyczna pełna była analogii do historii narodu wybranego, przejawiających się tak w mesjanizmie, jak i w toposie narodu uciemiężonego, pozbawionego wolności i opłakującego tę stratę ${ }^{28}$. Przypominają o tej, trochę zapomnianej już, tradycji na przykład wiersze Aleksandra Wata, wpisujące się w polsko-żydowskie opowiadanie o losie polskim przez opowieść o losie Izraelitów (np. aluzje do Psalmu 136/137 w Wierzbach w Ałma-Acie albo cytaty z wierszy Lenartowicza i Ujejskiego nawiązujących do tego samego psalmu w wierszu Na melodie hebrajskie). Odwołuje się do niej również Michał Borwicz, używając jako tytułu swej antologii cytatu z Pieśni Wajdeloty. Niektóre z pieśni Szlengla „uszły cało”, były też jak pieśń gminna - docierająca do wszystkich i mówiąca głosem ludu. Przez swoje świadectwo stanęły „na straży/ [n]arodowego pamiątek

${ }^{28}$ Na temat topiki psalmu 136(137) i jej związku z niewolą Polaków por. Burdziej B., 1999, Super flumina Babylonis. Psalm 136(137) w literaturze polskiej XIX-XX w., Toruń. 
kościoła” (Mickiewicz 2000, 27), na przykład uwznioślając w romantycznym stylu ostatni marsz Korczaka w Kartce $z$ dziennika „akcji”, ale „dzierżyły i broń archanioła” (tamże) jak wspomniany Kontratak, co „bunt wznieci[ł... n]a nowym Campo di Fiori" (Miłosz 2011, 194).

Wpisuje się niebezpośrednio w ten schemat również Okno na tamta. stronę. Cały wiersz, który wydaje się świadectwem tego, co widać z „bezczelnego żydowskiego okna”, poświadcza „podwójne kodowanie”. Poeta bowiem najprawdopodobniej nie mógł zobaczyć nic poza „aryjskimi drzewami”. Szlengel „kradnie zgaszoną Warszawę” (obowiązywało zaciemnienie), wylicza budynki oddzielone parkiem, dość odległe i najprawdopodobniej w ciemności nocy niemożliwe do zobaczenia. Poeta wsłuchuje się $\mathrm{w}$ odgłosy dochodzące $\mathrm{z}$ ciemności i zaczyna sentymentalną podróż w wyobraźni do ukochanego miasta, tak bliskiego i dalekiego zarazem. Księżyc, jeden z symboli romantycznej poezji i jej natchnień, jest tu ironicznie zredukowany do roli „Wachmeistra”, pozwalającego na „szmugiel sentymentalny". Oczy żarłocznie wbite w ciemność (,jak ostrza w pierś nocy utkwione" - zauważmy dobór słownictwa w wierszu, który sugeruje panującą wokół przemoc i grozę: „ostrza”, „kikuty”, „męka”, „trupio białe”) nie widzą nic. Cała scena odbywa się w wyobraźni poety. „Spoglądając przez okno na horror getta, widziało się bowiem swój własny los, patrzyło się na samego siebie" (Leociak 2016, 198). Szlengel też patrzy w siebie i w swoją podwójną tożsamość. Niczym Mickiewicz na stepach Akermanu, „zamyka oczy i szepce:/ Warszawo... odezwij się... czekam...". I niczym Mickiewicz musi sobie gorzko odpowiedzieć na koniec: „Jedźmy, nikt nie woła”, albo raczej, jak ukrywający się po drugiej stronie muru i równie boleśnie odczuwający obojętność współobywateli Jerzy Kamil Weintraub: „Jedźmy, nikt nie słyszy" (wiersz Kurhany, Weintraub 1986, 277).

Janusowe okno Szlengla jednocześnie spogląda na zewnątrz i do wewnątrz. Tak samo jak okno Korczaka, z którym Szlengel współpracował $\mathrm{w}$ getcie (tekst zaproszenia na ostatnie przedstawienie w sierocińcu jest autorstwa Szlengla), z którym łączyła go również miłość do Warszawy ${ }^{29}$ i podwójna tożsamość polsko-żydowska (o podwójnej świadomości Korczaka zob. Mitzner 2011, 132-133). W ostatnim z zapisków Pamiętnika, datowanym na 4.08.1942, Korczak prowadzi wewnętrzny dialog z widzianym przez okno wartownikiem (Korczak 2012, 136-140) ${ }^{30}$. Nie dowiadujemy się $\mathrm{z}$ tego dialogu wiele o Niemcu, ale za to dużo o humanistycznym spojrzeniu Korczaka, który próbuje nie widzieć w nim wroga i stara się go w wyobraźni zobaczyć jako człowieka ${ }^{31}$. Podobnie okno Szlengla pokazuje nam wnętrze,

\footnotetext{
${ }^{29}$ Możemy porównać miłość do rodzinnego miasta na przykładzie wierszy: Okno na tamta strone, Telefon czy Paszporty („Chciałbym mieć paszport Urugwaju, / mieć Costa Rica, Paragwaj/ po to by mieszkać spokojnie w Warszawie, / to jednak najpiękniejszy kraj", Szlengel 2013, 214) i znany cytat z Pamiętnika Korczaka $(2012,38)$ „Warszawa jest moja i ja jestem jej. Powiem więcej: jestem nią".

${ }^{30}$ Bardzo ciekawą reinterpretację owych ostatnich zapisków Korczaka zaproponowała autorka odkrywczej książki o Korczaku, Agnieszka Witkowska-Krych, w artykule Dziesięć ostatnich zapisków Janusza Korczaka, 2014, „Teksty Drugie”, nr 5 (89), s. 321-337.

${ }^{31}$ Warto w tym kontekście zwrócić uwagę na inne okno związane z Korczakiem. Amal, bohater sztuki Poczta Rabindranatha Tagore, na której przedstawienie w gettowym Domu Sierot Szlengel 
człowieka, który ma nie tylko okno wychodzące na tamtą stronę w pokoju na Świętojerskiej. Jego wewnętrzne okno na tamtą stronę ukazuje nam również jego polską romantyczną tożsamość. Jak wygląda ten obraz wnętrza?

Poeta, niczym kapłan, pontifex, pomost pomiędzy światami, podnosi ręce w magicznym rytuale przywołania. Zamiast głosu z zewnątrz, o który woła, słyszy głos z wewnątrz, z wyobraźni. Na jego rozpaczliwe wezwanie odpowiada wewnętrzny ideał. Koncert Szopena na sto fortepianów, spowodowany magicznym gestem poety, jest iluzją (przypomnijmy: po drugiej stronie okna jest rozległy park, a poza tym muzyka Szopena była zakazana podczas okupacji). Wewnętrzny obraz polskości Szlengla to obraz nierealny, stworzony przez fascynację romantycznym mitem. Polonez Szopena, melodia polskiego romantyzmu, to muzyka, która kazała wierzyć w walkę pod sztandarem z Lelewelowskim (ponoć) napisem „Za wolność naszą i waszą", w ideały braterstwa narodów i wspólnej walki. Szopen, kwintesencja polskiej duszy, symbol polskiego romantyzmu, gotowego do cierpienia i poświęceń za inne narody zderza się $\mathrm{z}$ „nabrzmiałą ciszą” po tamtej stronie. Idealistyczne wychowanie żydowskiego Kolumba w duchu polskiego romantyzmu zderza się z okrutną rzeczywistością obojętności i opuszczenia. Ideał romantycznego Polaka z jednej strony, a z drugiej - realia: stróż, który chodzi w futrze zagrabionym żydowskiemu poecie (Klucz u stróża), pomimo wcześniejszego (we wrześniu) braterstwa broni. Warto też w tym kontekście przytoczyć ostatni i najbardziej znany wiersz Zuzanny Ginczanki Non omnis moriar, która swoje rozczarowanie nieprzystającym do okrutnej antysemickiej rzeczywistości idealistycznym romantycznym mitem wyraża sarkastycznie, trawestując Testament mój Słowackiego. U Szlengla (2013, 196) wiersz Słowackiego wybrzmiewa gorzko w jego posłowiu do tomiku Co czytałem umarłym: „I to wszystko czytałem umarłym... A żywi... No, cóż... żywi niechaj nie tracą nadziei...”. Aby wyrazić wspólnotę ukształtowania oraz różnicę doświadczeń i pamięci, przypomnijmy, że z tej samej strofy wiersza pochodzi metafora użyta jako tytuł powieści Aleksandra Kamińskiego i często przywoływana w opisie losu pokolenia Kolumbów: „kamienie na szaniec”.

Okno na tamtą stronę, na fantazmaty polskości, w które poeta wierzył, powoduje tym boleśniejsze rozczarowanie. To dlatego źle jest mieć podwójną tożsamość, wewnętrzne „okno na tamtą stronę”, które daje wyidealizowany obraz polskości romantycznej, fascynującej, nierealnej, romantyczny fantazmat, który opisywała Maria Janion jako część naszej tożsamości zbiorowej. Ten sam fantazmat, z którym boleśnie musieli zmierzyć się i polscy Kolumbowie, tyle że u Szlengla jeszcze boleśniejszy, bo pojawiający się w wewnętrznym oknie odrzuconego sublokatora. „Źle jest / mieć okno na tamtą stronę", źle jest być pomiędzy światami, oczekiwać czegoś więcej od społeczeństwa postrzeganego przez pryzmat romantycznych ideałów,

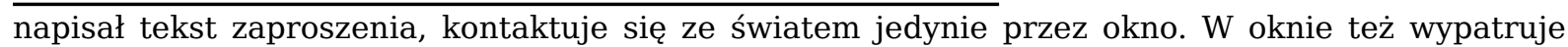
w momencie śmierci odwiedzin zapowiedzianego króla. 
będąc jednocześnie częściowo z tego powodu zdystansowanym wobec swej żydowskiej tożsamości (Przymuszała 2011).

Przez inne okno na tamtą stronę na dwa tygodnie przed śmiercią patrzy inny sublokator o podwójnej tożsamości - Adam Czerniaków. Notuje w swoim dzienniku (Czerniaków 1983, 298) w dniu 9 lipca 1942 z rozgoryczeniem, acz próbując znaleźć obiektywną odpowiedź: „Po obiedzie ulicznicy polscy ciskają kamienie przez murki na Chłodną. (...) Często zadawałem sobie pytanie, czy Polska, to jest Mickiewicz i Słowacki, czy też ten ulicznik? Prawda leży pośrodku"32.

Odrzucony, opuszczony poeta, głos „gettowe[go] 'my' warszawskiej, żydowskiej inteligencji” (Matywiecki 2012, 236) nie dostrzega, że jest widziany z tamtej strony, że współczują mu i widzą jego dramat. Wszyscy poeci to Żydzi? Patrząc na karuzelę po drugiej stronie Ogrodu Krasińskich trudno w to uwierzyć, a jednak poeta Miłosz pisze o wielkim Campo di Fiori, a słowo campo może być przetłumaczone również jako na zawsze naznaczone w polszczyźnie słowo obóz. Prawdopodobnie w okolicy innej z granic getta ${ }^{33}$ poetka Świrszczyńska patrzy w żydowskie okno, okno ukrywającego się po stronie „aryjskiej”:

\section{Okno}

Za dnia zawsze w tym oknie zapuszczone są firanki, wieczorem nigdy nie błyska tam światło.

Nocą otwiera to okno człowiek wykreślony z listy żywych. Patrzy na zamarłe, ciemne miasto. Słucha, czy u bramy nie zadźwięczy dzwonek.

Słucha oddalonego piania kogutów w najgłębszej godzinie nocy, kiedy wydaje się, że nigdy nie będzie już świtu (Świrszczyńska 1997, 109).

Przy skrzyżowaniu Chłodnej i Żelaznej, gdzie była brama getta, opodal dawnego mieszkania Szlengla na Walicowie, Białoszewski w poemacie Jerozolima przeczuwa, że:

Tam - - w męczeńskim mieście

wśród ulic jasnych i złych

między posągi trupów

\footnotetext{
${ }^{32}$ Polscy romantycy pojawiaja sie bardzo często w kontekstach bohaterstwa, rozczarowania i nawiązania do tradycji w tekstach prześladowanych Żydów. Przypomnę tu tylko, przepełniony „oddechem polskiej poezji romantycznej” (Janion 2009, 265), pamiętnik Calela Perechodnika (2011, cytaty m.in. ze Słowackiego - s. 73 i 167, i Mickiewicza - s. 101 i 238), pamiętnik Barucha Milcha $(2012,39)$ czy ostatnie przesłanie ukrywającego Archiwum Ringelbluma Dawida Grabera (Kassov $2010,16)$. Na nagrobku samego Czerniakowa, obok cytatu z Eklezjasty, znajduje się fragment wiersza Norwida Coś ty Atenom zrobił, Sokratesie...

${ }^{33}$ Pozwalają tak myśleć związki autorki z częścią Śródmieścia-Północ, będącą gettem i z nim graniczącą, gdzie po ucieczce z getta i po jego likwidacji znalazło schronienie najwięcej uciekinierów zza muru (zob. Engelking, Libionka, 2009, mapa pomiędzy s. 260-261). Kamienica, w której autorka mieszkała w czasie powstania warszawskiego, znajdowała się na ulicy Siennej, przez którą przebiegała przez jakiś czas granica getta. Barykada, której budowę uwieczniła, znajdowała się na Chmielnej, pomiędzy Zielną a Sosnową (w miejscu dzisiejszego Pałacu Kultury i Nauki), szpital powstańczy, w którym pracowała, to dawny Szpital Bersohnów i Baumanów (przed wojną pracował w nim Janusz Korczak, w czasie wojny gońcem w nim był Marek Edelman, a pracowały m.in. Adina Blady Szwajger, Anna Braude Hellerowa, Anna Margolis), ona sama urodziła się na Krochmalnej. Na tejże ulicy znajdowała się mydlarnia, którą jej matka dostała w posagu (informacje za Melion 1980, Nasiłowska 2014, 6-7 i Stechak 2017, 27). Sam cytowany wiersz powstał najpewniej już po wojnie i ukazał się w pierwszym powojennym tomiku Świrszczyńskiej Liryki zebrane (1958).
} 
błądzą psalmiści

grając na strunach zardzewiałych drutów:

„.......Jerozolimo....”

Nie słyszy nikt.

(Białoszewski 2017, 26)

„Chciałbym tylko milczeć/ a milcząc kłamię" napisze poeta Ficowski (2014, 157), chodząc po ruinach getta na Muranowie i sprzeciwiając się „egzekucji pamięci”... Milczenie nie jest żadną możliwością, kiedy wewnętrzny widok z sublokatorskiego okna na tamtą stronę niezmiennie prezentuje bolesne odrzucenie, wieczne splątanie tożsamości, zwłaszcza teraz, gdy „pełno ich nigdzie” (Ficowski 2014, 147). Powinniśmy cały czas pamiętać, że „jesteśmy mimo wszystko / stróżami naszych braci// niewiedza o zaginionych / podważa realność świata", jak pisał w wierszu Pan Cogito o potrzebie ścisłości Zbigniew Herbert (1998, 521). Milczenie jest jak zaniechanie, zbrodnia braci z Lilij (Żukowski 2005), jak obojętność i brak empatii, opisane w Campo di Fiori, dlatego wyzwaniem staje się ciągłe przywracanie pamięci tamtych poetów i tamtej rzeczywistości, ciągła nad nimi refleksja powodująca przemianę świadomości - jedyny prawdziwy bunt, jaki może wzniecić słowo poety. W przeciwnym razie milczenie powoduje, że nocą „będziemy zabijać umarłych” (wiersz Godzina dojrzała, Ficowski 2014, 176), że „łomotanie ciszy w ciszę” (Szymborska 2016, 62) wciąż Jeszcze zagłusza wołanie z tamtej strony, a widok cały czas pozostaje taki sam, jak w anonimowym wierszu z 1935 roku przetłumaczonym z jidysz przez Halinę Birenbaum:

Polsko, Ojczyzno moja, dzieciństwa duszo,

Ty jesteś jak wiecznie otwarta rana,

Dla tych, którzy Cię wiecznie kochać muszą,

Bo tysiąclecia kajdanami z nimiś związana.

Nagle łzy jak krwotok buchają ze mnie:

Polsko, kocham Cię wiecznie, potajemnie;

Niech milczy, kto Miłość zamilczeć może,

My, poeci, nie możem; smutno nam, Boże.

Polska Ty mowo, niby krwi bandażem, przesiąkłaś mą duszę;

Do Boga po polsku mówię, gdy wzywam Go na morzu,

przez burze,

Po polsku kocham - gdzieś w Nowym Jorku lub Singapurze,

Bo kiedykolwiek Miłość wyznaję - po polsku

wyznawać muszę.

(Anonim, bez daty)

\section{Bibliografia:}

Anonim, bez daty, Żydowski poeta z Polski, Birenbaum H. (przeł.), http://www. dialog.org/art_pl/wiersze-autornieznany.htm (dostęp: 18.12.2020). 
Białoszewski Miron, 2017, Polot nad niskimi sferami. Rozproszone i niepublikowane wiersze - przekłady poetyckie - dramaty - 1942-1970, Byliniak M., Sokołowska S. (oprac.), Warszawa.

Birenbaum Halina, 1998, Każdy odzyskany dzień. Wspomnienia, Sariusz-Skąpska I., (red.) Kraków.

Borwicz Michał, 1947, Pieśń ujdzie cało... Antologia wierszy o Żydach pod okupacja niemiecka, Warszawa-Łódź-Kraków.

Buryła Sławomir, 2013, Tematy (nie)opisane, Kraków.

Buryła Sławomir, 2019, Obraz getta warszawskiego w literaturze polskiej. Rekonesans, „Konteksty Kultury”, z. 1 (16), s. 33-51.

Czapliński Przemysław, 2015, Katastrofa wsteczna. „Poznańskie Studia Polonistyczne. Seria Literacka”, nr 25, s. 37-66.

Czapliński Przemysław, 2004, Zagłada jako wyzwanie dla refleksji o literaturze, „Teksty Drugie”, nr 5 (89), s. 9-22.

Czerniaków Adam, 1986, Dziennik getta warszawskiego 6 IX 1939-23 VII 1942, Fuks M. (oprac.), Warszawa.

Elias Norbert, Scotson John L., 1965, The Established and the Outsiders. A Sociological Enquiry into Community Problems, London.

Engelking Barbara, Libionka Dariusz, 2009, Żydzi w powstańczej Warszawie, Warszawa.

Ficowski Jerzy, 2014, Lewe strony widoków, Sommer P. (wybór i oprac.), Poznań.

Flatau Piotr J., Zimek Katarzyna, Lerski Tomasz, 2015, Wiemy więcej o Szlenglu. List opublikowany na stronie Żydowskiego Instytutu Historycznego: https://www.jhi.pl/blog/2015-09-08-wiemy-wiecej-o-szlenglu (dostęp: 16.04.2018).

Gross Natan, 1993, Poeci i Szoa. Obraz Zagłady Żydów w poezji polskiej, Sosnowiec.

Herbert Zbigniew, 2008, Wiersze zebrane, Krynicki R. (oprac.), Kraków.

Janicka Elżbieta, Tokarska-Bakir Joanna, Sublokatorstwo jako kategoria kultury polskiej, „Studia Litteraria Historica”, 2013, nr. 2, s. 1.

Janion Maria, 2009, Bohater, spisek, śmierć. Wykłady żydowskie, Warszawa.

Kassow Samuel D., 2010, Kto napisze nasza historię. Ukryte Archiwum Emanuela Ringelbluma, Waluga G., Zienkiewicz O. (przeł.), Warszawa.

Kisiel Marian, 2015, Między wierszami: jedenaście miniatur krytycznych, Katowice.

Koprowska Karolina, 2016, Doświadczenia zapisane $w$ rzeczach. O kilku wierszach Władysława Szlengla, „Ruch Literacki“, z. 3 (336), s. 327-341.

Korczak Janusz, 2012, Pamiętnik i inne pisma z getta, Ciesielska M. (przyp.), Leociak J. (posł.), Warszawa.

Kowalczyk Adam, 2015, Czarny humor w twórczości Władysława Szlengla ze szczególnym uwzględnieniem wiersza "Mała stacja Treblinki”, „Annales Universitatis Paedagogicae Cracoviensis. Studia Historicolitteraria”, nr 15, s. 121-129. 
Krall Hanna, 2017, Fantom bólu. Reportaże wszystkie, Kraków.

Kuczyńska-Koschany Katarzyna, 2013, „Bсе поэты жиды”. Antytotalitarne gesty poetyckie i kreacyjne wobec Zagłady oraz innych doświadczeń granicznych, Poznań.

Leminski Paulo, 2013, Powróciło moje polskie serce/Meu coração de polaco voltou, Kilanowski P., Szcześniak K. (przeł.), Katowice.

Leociak Jacek, 2016, Tekst wobec Zagłady. O relacjach z getta warszawskiego, Toruń.

Leociak Jacek, 2018, Doświadczenia graniczne. Studia o dwudziestowiecznych formach reprezentacji, Warszawa.

Lévine Madeleine G., 1999, Bezdomność w literaturze wojennej: typologia obrazowania, „Teksty Drugie”, nr 4 (57), s. 7-17.

Marat Emil, 2018, Sen Kolumba, Warszawa.

Matywiecki Piotr, 2012, Poezja, w: Buryła S., Krawczyńska D., Leociak J. (red.), Literatura polska wobec Zagłady (1939-1968), Warszawa, s. 174-239.

Melion Katarzyna, 1980, Budowałam barykadę, reportaż radiowy z udziałem Anny Świrszczyńskiej, https://www.polskieradio.pl/80/1007/Artykul/411766, Budowalam-barykade-reportaz-Krystyny-Melion (dostęp: 16.04.2021).

Mickiewicz Adam, 2000, Konrad Wallenrod, Gdańsk.

Milch Baruch, 2012, Testament, Żbikowski A. (posł. i przyp.), Warszawa.

Miłosz Czesław, Wiersze wszystkie, Kraków.

Mitzner Piotr, 2011, Biedny język. Szkice o kryzysie słowa i literaturze wojennej, Warszawa.

Morawiec Arkadiusz, 2015, Szlengel w Parku Krasińskich, „Tekstualia”, nr 1 (40), s. 37-53.

Najberg Leon, 1993, Ostatni powstańcy getta, Warszawa.

Nasiłowska Anna, 2014, Tragizm i solidarność w powstaniu, w: Świrszczyńska A., Budowałam barykade, Warszawa.

Panas Władysław, 1996, Pismo i rana. Szkice o problematyce $\dot{z} y d o w s k i e j ~ w ~ l i t e-$ raturze polskiej, Lublin.

Patalas Agata, 2018, Proza Irit Amiel wobec „sublokatorstwa” jako kategorii kulturowej („osmaleni” wobec „sublokatorek” $i$ „sublokatorów”), w: Janus-Sitarz A., Kania A. (red.), Historia najnowsza w literaturze i kulturze a edukacja polonistyczna, Kraków.

Perechodnik Calel, 2011, Spowiedź, Engel D. (oprac.), Warszawa.

Przymuszała Beata, 2011, Skaza $\dot{z y d o w s k o s ́ c i . ~ P r o b l e m ~ t o z ̇ s a m o s ́ c i ~ e t n i c z n e j ~}$ w tekstach poetyckich z czasów Zagłady. „Świat Tekstów. Rocznik Słupski”, nr 9, s. 151-160.

Ringelblum Emanuel, 1983, Kronika getta warszawskiego: wrzesień 1939 - styczeń 1943, Eisenach A. (oprac.), Rutkowski A. (przeł.), Warszawa.

Rogoziński Szymon, 1994, Moje szczęśliwe życie, Łódź. 
Schulz Bruno, 2019, Opowiadania. Wybór esejów i listów, Jarzębski J. (oprac.), wyd. elektroniczne, Wrocław.

Shallcross Bożena, 2010, Rzeczy i Zagłada, Kraków.

Skwara Marian, 2003, Słowo wyniesione z getta: wiersze Władysława Szlengla, „Pamiętnik Literacki”, z. 3 (94), s. 193-197.

Stechak Oleksandra, 2017, „Teraz pozostana po nim już tylko obrazy...”: pamięć o ojcu-artyście w wierszach Anny Świrszczyńskiej, Sztokholm, https://www. slav.su.se/polopoly fs/1.362142.1513264212!/menu/standard/file/Examensarbete\%2019.12.2017.\%200leksandra\%20Stechak\%20.pdf (dostęp: 16.04.2021).

Szlengel Władysław, 1979, Co czytałem umarłym. Wiersze getta warszawskiego, Maciejewska I. (oprac.), wyd. drugie, uzupełnione i poprawione, Warszawa.

Szlengel Władysław, 2013, Poeta nieznany. Wybór tekstów, Stańczuk M. (oprac.), Warszawa.

Szlengel Władysław, 2018, A janela para o outro lado. Poemas do Gueto de Varsóvia, Kilanowski P. (oprac., przeł.), Fortaleza.

Szymborska Wisława, 2016, Wybór poezji, Ligęza W. (oprac.), Wrocław.

Ślady obecności, 2010, Buryła S., Molisak A. (red.), Kraków.

Świrszczyńska Anna, 1997, Poezja, Miłosz Cz. (oprac.), Warszawa.

Weintraub Jerzy Kamil, 1986, Utwory wybrane, Matuszewski R. (wybór i wstęp), Warszawa.

Wołk Marcin, 2011, Język nasz, język ich. Jeszcze o wariantach tekstowych Campo di Fiori. „Archiwum Emigracji: studia - szkice - dokumenty”, z. 1-2 (14-15), s. 21-32.

Wójcik Michał, Marat Emil, Likiernik Stanisław, 2014, Made in Poland. Opowiada jeden z ostatnich żołnierzy Kedywu Stanisław Likiernik, Warszawa.

Żółkiewska Agnieszka, Tuszewicki Marek, 2017, Archiwum Ringelbluma. Konspiracyjne Archiwum Getta Warszawy, tom 26. Utwory literackie z getta warszawskiego, Warszawa.

Żukowski Tomasz, 2004, Kręgiem ostrym rozdarty na pół. O niektórych wierszach K.K. Baczyńskiego z lat 1942-1944, „Teksty Drugie”, nr 3 (87), s. 145-162.

Żukowski Tomasz, 2005, Ballady o Szoa, w: Głowiński M., Chmielewska K., Makaruk K., Molisak A., Żukowski T. (red.), Stosowność i forma. Jak opowiadać o Zagładzie, Kraków.

Żukowski Tomasz, 2010, Władysław Szlengel. Ironia a strategia świadectwa, w: Ślady obecności, Buryła S., Molisak A. (red.), Kraków.

\section{O Autorze:}

Piotr Kilanowski, prof. dr, tłumacz, wykładowca literatury polskiej w Katedrze Polonistyki Uniwersytetu Federalnego Parany w Kurytybie (Brazylia), którą kierował w latach 2011-2014, obecnie szef Departamentu Polonistyki, Germanistyki i Filologii Klasycznej na tym uniwersytecie. Jego zainteresowania naukowe związane są z literaturą polską XX wieku, ze 
szczególnym naciskiem na poezję, dzieło Zbigniewa Herberta oraz literaturę Zagłady. Autor wielu publikacji popularyzujących literaturę polską w Brazylii. Przełożył na język polski m.in. poezje Paula Leminskiego Powróciło moje polskie serce (Katowice 2014, Curitiba 2015), a na język portugalski m.in. tomy Zbigniewa Herberta A viagem do Senhor Cogito (Katowice 2016) i Senhor Cogito. Anotações da Casa Morta (São Paulo 2019), Anny Świrszczyńskiej Eu construía a barricada (Curitiba 2017), Jerzego Ficowskiego A leitura das cinzas (Veneza - Belo Horizonte 2018), Władysława Szlengla $A$ janela para o outro lado (Fortaleza 2018), Wisławy Szymborskiej Riminhas para as crianças grandes (Belo Horizonte 2018, współautorka Eneida Favre) oraz Irit Amiel Não cheguei a Treblinka a tempo (Fortaleza 2019). W czasopismach ukazały się również w jego przekładzie utwory m.in.Josifa Brodskiego, Jana Kochanowskiego, Ignacego Krasickiego, Cypriana Kamila Norwida, Bolesława Leśmiana, Zuzanny Ginczanki, Marii Pawlikowskiej-Jasnorzewskiej, Władysława Broniewskiego, Antoniego Słonimskiego, Aleksandra Wata, Czesława Miłosza, Tadeusza Gajcego, Tadeusza Różewicza, Mirona Białoszewskiego, Stanisława Barańczaka, Ryszarda Krynickiego, Juliana Kornhausera, Adama Zagajewskiego, Jacka Kaczmarskiego, Tomasza Różyckiego, Krystyny Dąbrowskiej, Ewy Lipskiej i Stanisława Lema. Odznaczony srebrnym medalem Zasłużony Kulturze Gloria Artis (2018). 
